20. Clements R. An investigation of the status of outdoor play. Contemporary Issues in Early Childhood. 2004; 5(1): 68-80.

Цитування на цю статтю:

Кравченко ТП. Оптимізація фізичної підготовленості учнів молодшого шкільного віку засобами рухливих ігор в умовах нової української школи. Вісник Прикарпатського університету. Серія: Фізична культура. 2019 Берез 26; 33: 40-51

\begin{tabular}{l|l} 
Відомості про автора: & Information about the author: \\
\hline Кравченко Тетяна Петрівна - кандидат педагогіч- & Kravchenko Tetiana Petrivna - Candidate of Science \\
них наук, доцент, Переяслав-Хмельницький Дер- & (Education), Associate Professor (Ph. D.), Gregory \\
жавний педагогічний університет імені Григорія & Skovoroda Pereyaslav-Khmelnytsky State Pedagogical \\
Сковороди (Переяслав-Хмельницький Україна) & University (Pereyaslav-Khmelnytsky, Ukraina) \\
\hdashline e-mail: galenko-tanya @ rambler.ru & \\
https://orcid.org/0000-0002-6041-3101 & \\
\hline
\end{tabular}

УДК 378:796.8

doi: 10.15330/fcult.33.51-56

Едуард Лапковський, Ярослав Яців, Богдан Лісовський

\title{
ПРОГРАМА УДОСКОНАЛЕННЯ СПЕЦІАЛЬНОЇ ФІЗИЧНОЇ ПІДГОТОВКИ БОРЦІВ ВІЛЬНОГО СТИЛЮ ТА ЇЇ ВПЛИВ НА ЕФЕКТИВНІСТЬ ЗМАГАЛЬНОї ДІЯЛЬНОСТІ
}

\begin{abstract}
Мета. Теоретично обгрунтувати й розробити програму спеціальної фізичної підготовки бориів вільного стилю та перевірити ї̈ вплив на ефективність їх змагальної діяльності. Методи. У процесі виконання дослідження були застосовані аналіз наукової $і$ спеціальної літератури; педагогічне спостереження (вивчення результативності змагальної діяльності), педагогічний експеримент, методи математичної статистики. У педагогічному експерименті взяли участь 10 студентів-бориів вільного стилю у віиі від 18 до 20 років. Аналіз змагальної діяльності бориів проводили як безпосередньо в ході поєдинків, так $і$ в процесі перегляду відеозаписів. Визначали наступні показники змагальної діяльності: тривалість реальних атак, інтервали часу, через які поновлюються атаки, інтервал між успішними атаками, тривалість успішних атак, кількість отриманих балів, загальна тривалість сутички, кількість перемог та поразок. Результати. Для ефективного управління процесом розвитку швидкісносилових якостей студентів-спортсменів, які займаються вільною боротьбою було сформовано шість мікроциклів тренувань із використанням комбінацій вправ певного характеру впливу (розвиваючого фізично/технічно, контролюючого, підвідного, змагального, відновлювального). Особливість застосованої нами методики під час реалізаиії програми швидкісно-силового удосконалення бориів полягала в тому, щзо в період безпосередньої підготовки до змагань (за 21-28 днів) обсяг вправ із партнером досягав 70-80\%. Порівняння результативності змагальної діяльності до і після реалізації програми педагогічного експерименту дозволило встановити вірогідне збільшення часу реальних атак, зменшення інтервалу між атаками, зростання кількості успішних атак. Як наслідок, збільшилася кількість перемог на фоні сталого числа поразок. Висновок. Отже реалізація експериментальної програми удосконалення спеціальної фізичної підготовки бориів вільного стилю забезпечила покращення змагальної діяльності спортсменів, щзо підтверджено вірогідним зростанням тривалості реальних атак, зменшенням тривалості інтервалів між атаками, збільшенням кількості успішних атак та часу безпосередньої активної взаємодї з суперником. Як наслідок - зросла загальна кількість перемог на фоні незмінного числа поразок.
\end{abstract}

Ключові слова: борці вільного стилю, програма, спеціальна фізична підготовка, змагальна діяльність.

The purpose of the work was to evaluate the results of the competitive activity of the student-wrestlers after the application of the developed training program in the annual cycle. In the course of the research, the analysis of scientific and special literature was applied; pedagogical observation and experiment; pedagogical testing (studying the effectiveness of competitive activities), methods of mathematical statistics.

The analysis of the competitive activity of the student-wrestlers was conducted both directly during the matches, and in the process of video replay. The following indicators of the competitive activity of the student- 
wrestlers were determined: the duration of real attacks, the interval of attacks - the intervals of time, through which attacks are made, the interval of successful attacks - the intervals of time, through which they are produced, the duration of successful attacks, the number of points won, the duration of the fight - the time from it beginning before the actual ending, the number of victories, the number of losses. In the pedagogical experiment, participated 10 free style wrestlers aged 18 to 20 years. The research was conducted on the basis of the Vasyl Stefanyk Precarpathian National University.

For effective control of the development of the speed-strength qualities of students engaged in free struggle, 6 microcycles of training were formed using combinations of exercises of a certain nature (developing (physically / technically), control, preparatory, competitive, restorative).

The proposed program of development of speed-strength qualities of student-wrestlers provided a reliable growth of the values of an anaerobic component of special endurance, an increase in its power and speed-power components by the results of tests in squatting with the partner of its weight and pulling up the jerk on the crossbar.

The result of the training program we introduced was the improvement of competitive activities, which was confirmed by the probable increase in the duration of real attacks, a decrease in the time interval between attacks, an increase in the time of successful attacks and an increase in the duration of the match in general. As a result, the total number of victories grew against the backdrop of an unchanging number of losses.

The absence of changes in muscle strength of the abdominal press was recorded, which in the long run proves the need to improve our training program with emphasis on the effectiveness of selected exercises.

Key words: free style fighters, program, special physical training, competitive activities.

Постановка проблеми й аналіз результатів останніх досліджень. У теорії і практиці спорту основним засобом для розвитку функціональних резервів периферійного нервово-м'язового апарату, сили і швидкості скорочення скелетних м’язів вважається тренування з обтяженнями (вправи зі штангою, гантелями, гирями, з вагою власного тіла і спаринг-партнера), а також вправи на тренажерних пристроях $[1,3]$.

Динамічне зростання рівня спортивної майстерності у вільній боротьбі, вимагає пильної уваги щодо вдосконалення всіх сторін підготовки, від яких залежать спортивні досягнення. До числа таких факторів відносять спеціальну фізичну підготовленість, яка регламентується рівнем розвитку таких фізичних якостей як силові, швидкісні, швидкісно-силові та координаційні здібності, а також анаеробна працездатність. При цьому велику роль відіграє функціональний стан нервово-м'язової системи яка $є$ істотним фактором рухових можливостей спортсмена [5].

Відомо, що швидкісно-силові здібності проявляються у вправах зі значним напруженням м'язів і високою швидкістю їх скорочення. А якісним їх відображенням $\epsilon$ вибухова сила $[2,4]$.

У процесі удосконалення швидкісно-силових якостей борців існують певні протиріччя. 3 одного боку, в тренувальних вправах, що використовуються 3 цією метою, напруга і розслаблення окремих м'язових груп носять циклічний характер [7].

3 іншого боку - в реальному змагальному поєдинку спортсмени знаходяться в умовах перманентної силової взаємодії з суперником, а їх нервово-м'язовий апарат (нейро-моторні одиниці) в стані значної рекрутизації, особливо в початковій фазі проведення будь-якої технічної дії $[6,8]$.

Аналіз науково-методичної літератури свідчить про те, що на сучасному етапі розвитку вільної боротьби роль спеціальної фізичної підготовки борців зростає. При цьому показано, що регламент сучасного поєдинку, незалежно від конкретної формули, значно інтенсифікує його і акцент в методиці розвитку рухових якостей змістився від удосконалення м'язової сили до швидкісно-силової м'язової витривалості [9].

Вивчаючи проблему інтенсифікації навчально-тренувального процесу в зв'язку зі зміною регламенту змагань, вчені визначили час проведення активних та пасивних дій спортсменів. На підставі цих даних запропоновано інтенсифікувати навчально-тренувальний процес шляхом удосконалення структури тижневого мікроциклу. Для цього за- 
пропоновано змінити розподіл тренувальних днів з піковими і малими навантаженнями, а також співвідношення тривалості фізичного навантаження й інтервалу відпочинку на кожному тренувальному занятті. При цьому запропоновано більш широко впроваджувати триразові тренування зі скороченням їх тривалості, але зі збільшенням інтенсивності. Така побудова тренувального процесу є сприятливою для зростання потужності і ємності анаеробних джерел енергії (фосфагенного і гліколітичного), які $є$ головними в забезпеченні змагальної діяльності спортсменів-борців [8].

Із огляду на вище сказане, розробка ефективних програм удосконалення функціональних резервів нервово-м'язової системи борців вільного стилю та їх швидкісносилових здібностей $є$ актуальним науковим завданням.

Мета дослідження - теоретично обгрунтувати й розробити програму спеціальної фізичної підготовки борців вільного стилю та перевірити іiі вплив на ефективність їх змагальної діяльності

Методи й організація дослідження. У процесі виконання дослідження були застосовані аналіз наукової і спеціальної літератури; педагогічне спостереження (вивчення результативності змагальної діяльності) та педагогічний експеримент, методи математичної статистики (розрахунок достовірності різниці отриманих результатів із використанням t-критерію Стьюдента)

У педагогічному експерименті взяли участь 10 студентів-борців (чоловіки) вільного стилю у віці від 18 до 20 років на етапі попередньої базової підготовки. Дослідження проводилося на базі ДВНЗ "Прикарпатський національний університет імені Василя Стефаника".

Аналіз змагальної діяльності борців проводили як безпосередньо в ході поєдинків, так і в процесі перегляду відеозаписів. За загальноприйнятими методиками визначали наступні показники змагальної діяльності борців вільного стилю: тривалість реальних атак, інтервали часу, через які поновлюються атаки, інтервал між успішними атаками, тривалість успішних атак, кількість отриманих балів, загальна тривалість сутички, кількість перемог та поразок.

Результати і дискусія. Одними з ефективних засобів удосконалення швидкісносилових якостей борців вважаються гімнастичні і спеціальні вправи з обтяженням та опором партнера. Як обтяження використовуються: спаринг-партнери, борцівський манекен, штанга, гирі, гантелі, набивні м’ячі, блочні пристрої, еспандери, гумові амортизатори тощо. Ефективним $є$ також виконання окремих прийомів і проведення сутичок зі спаринг-партнерами, що мають кращий рівень розвитку силових здібностей головних груп скелетних м'язів або є представниками вищої вагової категорії [6].

Як відомо, у борців вільного стилю особливо розвинуті швидкісно-силові якості, які забезпечують надійність та ефективність виконання техніко-тактичних дій під час змагальної діяльності.

Біомеханічний аналіз техніки вільної боротьби дозволив встановити головні групи скелетних м'язів, які забезпечують виконання сукупності технічних прийомів/контрприйомів та опору партнерів під час сутички. Серед них такі: розгиначі тулуба, м'язи плечового пояса, розгиначі суглобів нижніх кінцівок ніг, м'язи черевного пресу. Для удосконалення сили і швидкості скорочення цих м'язів доцільно використовувати такі фізичні вправи: вправи з обтяженнями, ізометричні вправи зі швидким напруженням м'язів, стрибкові вправи, вправи з ударним режимом роботи м'язів, поєднання в одному завданні вправ різного характеру впливу з використанням методу колового тренування.

Структура спеціальних вправ залежить від цільової спрямованості тренування i рівня підготовленості борців. Загальновизнаними педагогічними методами в спортивних єдиноборствах є імітація протиборства, тобто формальне моделювання технічного 
прийому або окремої його фази, функціональне моделювання ситуацій змагального протиборства.

Для ефективного управління процесом розвитку швидкісно-силових якостей студентів-спортсменів, які займаються вільною боротьбою було сформовано шість мікроциклів тренувань із використанням комбінацій вправ певного характеру впливу (розвиваючого - фізично/технічно, контролюючого, підвідного, змагального, відновлювального) (табл. 1).

Особливість застосованої нами методики під час реалізації програми швидкісносилового удосконалення борців полягала в тому, що в період безпосередньої підготовки до змагань (за 21-28 днів) обсяг вправ із партнером досягав 70-80\%. Це здійснювалося для посилення стресостійкості спортсменів і зменшення ризику втрати м'язової чутливості. При цьому швидкісно-силова підготовка органічно поєднувалася 3 технічним удосконаленням.

Таблиия 1

Розподіл вправ по мікроциклах тренувань для розвитку швидкісно-силових якостей борців вільного стилю

\begin{tabular}{|c|c|c|}
\hline № $3 / \Pi$ & Мікроцикли & Вправи \\
\hline 1 & $\begin{array}{l}\text { Розвиваючий } \\
\text { (фізично) }\end{array}$ & $\begin{array}{ll}\text { - } & \text { гімнастичні } \\
\text { - } & \text { спеціально-підготовчі (розвиваючі) } \\
\text { - } & \text { змагальні } \\
\end{array}$ \\
\hline 2 & $\begin{array}{l}\text { Розвиваючий } \\
\text { (технічно) }\end{array}$ & $\begin{array}{l}\text { • } \quad \text { спеціально-підготовчі (розвиваючі) } \\
\text { - } \quad \text { змагальні }\end{array}$ \\
\hline 3 & Контрольний & $\begin{array}{l}\text { • } \quad \text { спеціально-підготовчі (розвиваючі) } \\
\text { • } \quad \text { змагальні }\end{array}$ \\
\hline 4 & Підвідний & $\begin{array}{ll}\text { • } & \text { змагальні } \\
\text { • } & \text { спеціально-підготовчі (розвиваючі) }\end{array}$ \\
\hline 5 & Змагальний & $\begin{array}{ll}\text { • } & \text { змагальні } \\
\text { • } & \text { спеціально-підготовчі (розвиваючі) }\end{array}$ \\
\hline 6 & Відновний & $\begin{array}{l}\text { • } \quad \text { гімнастичні; } \\
\text { • } \quad \text { спеціально-підготовчі (розвиваючі). }\end{array}$ \\
\hline
\end{tabular}

Порівняння результативності змагальної діяльності до і після реалізації програми педагогічного експерименту дозволило встановити вірогідне збільшення часу реальних атак, зменшення інтервалу між атаками, зростання кількості успішних атак. Як наслідок, збільшилася кількість перемог на фоні сталого числа поразок (табл. 2).

Таблиия 2

Зміна показників змагальної діяльності студентів-борців вільного стилю після закінчення педагогічного експерименту

\begin{tabular}{|l|c|c|}
\hline \multirow{2}{*}{ Показники змагальної діяльності } & \multicolumn{2}{|c|}{ Педагогічний експеримент } \\
\cline { 2 - 3 } & До & Після \\
\hline Тривалість реальних атак, с & $5,61 \pm 0,09$ & $5,95 \pm 0,08^{*}$ \\
\hline Інтервал атак, с & $45,7 \pm 1,13$ & $37,5 \pm 1,21^{*}$ \\
\hline Тривалість успішних атак, с & $3,71 \pm 0,01$ & $4,32 \pm 0,02^{*}$ \\
\hline Кількість виграних балів, бали & $5,13 \pm 0,06$ & $6,92 \pm 0,07^{*}$ \\
\hline Тривалість поєдинку, хв & $4,22 \pm 0,05$ & $4,72 \pm 0,0,04^{*}$ \\
\hline Кількість перемог & $22,5 \pm 1,12$ & $26,5 \pm 1,14^{*}$ \\
\hline Кількість поразок & $8,12 \pm 0,13$ & $7,82 \pm 0,14^{*}$ \\
\hline
\end{tabular}

Примітка. ${ }^{*}-\mathrm{p}<0,05$. 


\section{Висновок}

Отже реалізація експериментальної програми удосконалення спеціальної фізичної підготовки борців вільного стилю забезпечила покращення змагальної діяльності спортсменів, що підтверджено вірогідним зростанням тривалості реальних атак, зменшенням тривалості інтервалів між атаками, збільшенням кількості успішних атак та часу безпосередньої активної взаємодії з суперником. Як наслідок - зросла загальна кількість перемог на фоні незмінного числа поразок.

1. Арзютов ГМ, Агеєв ПМ, Саенко СВ. Методика ефективного навчання техніки в єдиноборствах. Науковий часопис Національного педагогічного університету ім. М. П. Драгоманова (Науково педагогічні проблеми фізичної культури Фізична культура і спорт : Зб. наук. праць. Київ. 2011; (12): 3-8.

2. Калмыков СВ. Проявление быстроты у борцов различного возраста и квалификации. Теория и практика физической культуры. “Физкультура и спорт”. 2008; 11: 35-37.

3. Киракосян ОЕ. Контрольные упражнения для оценки силовой подготовленности борцов. Теория и практика физической культуры. 2002; 10: 46-48.

4. Козляков АВ. Силовая подготовленность борцов вольного стиля различной квалификации. Учёные записки университета им. П.Ф. Лесгафта. 2010; 9(67): 43-49.

5. Медведь АВ, Шахлай АМ, Медведь АА. Совершенствование годичного цыкла подготовки борцов высокой квалификации. Мир спорта. 2009; 1: 3-6.

6. Пакулін СЛ, Ананченко КВ, Ручка СВ. Вдосконалення техніко тактичної та психологічної підготовки борців вільного стилю. Траєкторія науки. 2016; 12: 9.1-9.12.

7. Попов ЮА. Проблемы подготовки спортивного резерва. Вестник спортивной науки. 2010; 1: 15-18.

8. Шиян ВВ. Научные исследования в спортивной борьбе как способ совершенствования учебного материала при подготовке специалистов. Теория и практика физической культуры. 2007; 2: 5-6.

9. Яців ЯМ, Лапковський ЕЙ. Аналіз сучасних поглядів на визначення ефективності впливу фізичних навантажень на організм студентів. Вісник Прикарпатського університету. Фізична культура. 2014; 20: $103-107$

\section{Referencess}

1. Arziutov HM, Aheiev PM, Saenko SV. Metodyka efektyvnoho navchannia tekhniky v yedynoborstvakh. Naukovyi chasopys Natsionalnoho pedahohichnoho universytetu im. M. P. Drahomanova (Naukovo pedahohichni problemy fizychnoi kultury Fizychna kultura i sport : Zb. nauk. prats. Kyiv. 2011; (12): 3-8.

2. Kalmykov SV. Proiavlenye bystroty u bortsov razlychnoho vozrasta i kvalifikatsii. Teoryia y praktyka fyzycheskoi kultury. "Fizkultura i sport". 2008; 11: 35-37.

3. Kirakosian OE. Kontrolnye uprazhnenyia dlia otsenky sylovoi podhotovlennosty bortsov. Teoryia i praktyka fyzycheskoi kultury. 2002; 10: 46-48.

4. Kozliakov AV. Sylovaia podhotovlennost bortsov volnoho stylia razlychnoi kvalyfykatsyy. Uchenye zapysky unyversyteta im. P.F. Leshafta. 2010; 9(67): 43-49.

5. Medved AV, Shakhlai AM, Medved AA. Sovershenstvovanye hodychnoho tsykla podhotovky bortsov vysokoi kvalyfykatsyy. Myr sporta. 2009; 1: 3-6.

6. Pakulin SL, Ananchenko KV, Ruchka YeV. Vdoskonalennia tekhniko taktychnoi ta psykholohichnoi pidhotovky bortsiv vilnoho styliu. Traiektoriia nauky. 2016; 12: 9.1-9.12.

7. Popov YuA. Problemy podhotovky sportyvnoho rezerva. Vestnyk sportyvnoi nauky. 2010; 1: 15-18.

8. Shyian VV. Nauchnye issledovanyia v sportyvnoi borbe kak sposob sovershenstvovanyia uchebnoho materyala pry podhotovke spetsyalystov. Teoryia i praktyka fyzycheskoi kultury. 2007; 2: 5-6.

9. Iatsiv YaM, Lapkovskyi EI. Analiz suchasnykh pohliadiv na vyznachennia efektyvnosti vplyvu fizychnykh navantazhen na orhanizm studentiv. Visnyk Prykarpatskoho universytetu. Fizychna kultura. 2014; 20: 103107

\section{Цитування на цю статтю:}

Лапковський ЕИ, Яців ЯМ, Лісовський БП. Програма удосконалення спеціальної фізичної підготовки борців вільного стилю та іï вплив на ефективність змагальної діяльності. Вісник Прикарпатського університету. Серія: Фізична культура. 2019 Берез 26; 33: 51-56

\begin{tabular}{l|l|l} 
Відомості про автора: & Information about the author: \\
\hdashline Лапковський Едуард Иосипович - кандидат ме- & Lapkovskyi Eduard Yosypovych - Candidate of \\
дичних наук, доцент, ДВНЗ “Прикарпатський на- & Science (Medicine), Associate Professor (Ph. D.), Vas- \\
\hline
\end{tabular}




\begin{tabular}{|c|c|}
\hline $\begin{array}{l}\text { ціональний університет імені Василя Стефаника" } \\
\text { (Івано-Франківськ, Україна) }\end{array}$ & $\begin{array}{l}\text { yl Stefanyk Precarpathian National University (Ivano- } \\
\text { Frankivsk, Ukraine) }\end{array}$ \\
\hline \multicolumn{2}{|l|}{$\begin{array}{l}\text { e-mail: edlap55@gmail.com } \\
\text { http://orcid.org/0000-0002-7717-2236 }\end{array}$} \\
\hline $\begin{array}{l}\text { Яців Ярослав Миколайович - кандидат педаго- } \\
\text { гічних наук, професор, декан факультету фізичного } \\
\text { виховання і спорту, ДВНЗ “Прикарпатський націо- } \\
\text { нальний університет імені Василя Стефаника” (Іва- } \\
\text { но-Франківськ, Україна) }\end{array}$ & $\begin{array}{l}\text { Yatsiv Yaroslav Mykolaiovych - Candidate of Science } \\
\text { (Education), Professor, Dean of the Faculty of Physical } \\
\text { Education and Sports, Vasyl Stefanyk Precarpathian } \\
\text { National University (Ivano-Frankivsk, Ukraine) }\end{array}$ \\
\hline \multicolumn{2}{|l|}{$\begin{array}{l}\text { e-mail: yatsiv64@ gmail.com } \\
\text { http://orcid.org/0000-0003-2474-0401 }\end{array}$} \\
\hline $\begin{array}{l}\text { Лісовський Богдан Петрович - кандидат біоло- } \\
\text { гічних наук, доцент, ДВНЗ “Прикарпатський на- } \\
\text { ціональний університет імені Василя Стефаника" } \\
\text { (Івано-Франківськ, Україна) }\end{array}$ & $\begin{array}{l}\text { Lisovskyi Bohdan Petrovych - Candidate of Science } \\
\text { (Biology), Associate Professor (Ph. D.), Vasyl Stefa- } \\
\text { nyk Precarpathian National University (Ivano- } \\
\text { Frankivsk, Ukraine) }\end{array}$ \\
\hline $\begin{array}{l}\text { e-mail: lisovsky.bogdan@ gmail.com } \\
\text { https://orcid.org/0000-0003-0474-9572 }\end{array}$ & \\
\hline
\end{tabular}

УДК 378.147.7.96-051[005.342

doi: 10.15330/fcult.33.56-62

Андрій Молдован

\section{ДО ПИТАННЯ ПРО ПІДГОТОВКУ МАЙБУТНІХ ФАХІВЦІВ 3 ФІЗИЧНОГО ВИХОВАННЯ І СПОРТУ ДО ПІДПРИЕМНИЦЬКОЇ ДІЯЛЬНОСТІ В РЕАЛІЯХ ПОСТІНДУСТРІАЛЬНОГО СУСПІЛЬСТВА}

Особливою рисою постіндустріального суспільства є важливість інформації для економічного $і$ соціального прогресу. Саме це дозволяе говорити про інтелектуалізацію економіки, про економіку, що базується на знаннях. У зв'язку з иим уряди, підприємиі, громадськість більшості краӥн світу все більше усвідомлюють, як важливо мати якісну інформачію з широкого кола питань. Це дозволяє забезпечити раціональне прогнозування та керування економічними і соціальними процесами для прийняття науково обгрунтованих рімень з різноманітних і складних проблем суспільного розвитку.

У статті розглянуто теоретичні основи підприємництва, тенденції та проблеми розвитку фiзичної культури та спорту, передумови розвитку підприємницької діяльності у сфері фізичної культури та спорту. Проаналізовано функиії підприємництва у галузі фізичної культури і спорту. Охарактеризовано відмінні риси різних організаційно-правових форм спортивних комерційних організацій. На цій основі обтрунтовано значення сфери фізичної культури і спорту як соціальної системи, розкрито організаційну структуру управління вітчизняним фізкультурно-спортивним рухом, охарактеризовано особливості функиіонування иієї системи на сучасному етапі.

Професійна підготовка майбутніх фахівців у сфері фізичної культури $і$ спорту до підприємницької діяльності була зумовлена швидкими змінами в сочіально-економічному, політичному житті країни, викликами глобалізації, об'єктивними потребами підвищення якості зростанням рівня вимог до навчально-методичного, науково-методччного та інформачійного забезпечення професійної компетентності цих фахівців з урахуванням їхніх особистісно-професійних запитів і потреб, професійного досвіду.

Тому все актуальнішими стають проблеми підвищення якості підготовки майбутніх фахівців у сфері фізичної культури до підприємницької діяльності в реаліях сьогоднішнього постіндустріального суспільства.

Ключові слова: постіндустріального суспільства, підприємницька діяльність, фізична культура $і$ cnopm.

Objective: a Special feature of post-industrial society is the importance of information for economic and social progress. This is what allows us to talk about the intellectualization of the economy, the economy based on knowledge. In this regard, governments, entrepreneurs, the public in most countries of the world are increasingly aware of the importance of having quality information on a wide range of issues. It allows to provide rational forecasting and management of economic and social processes for making scientifically proved decisions from various and difficult problems of social development. 